\title{
Observations on the President's Fiscal Year 1999 Federal Science and Technology Budget
}

Committee on Science, Engineering, and Public Policy

NATIONAL ACADEMY OF SCIENCES

NATIONAL ACADEMY OF ENGINEERING

INSTITUTE OF MEDICINE

NATIONAL ACADEMY PRESS

Washington, D.C. 20418 


\section{NATIONAL ACADEMY PRESS • 2101 Constitution Avenue, N.W. • Washington, DC 20418}

NOTICE: This volume was produced as part of a project approved by the Governing Board of the National Research Council, whose members are drawn from the councils of the National Academy of Sciences, the National Academy of Engineering, and the Institute of Medicine. It is a result of work done by the Committee on Science, Engineering, and Public Policy (COSEPUP) as augmented, which has authorized its release to the public. This report has been reviewed by a group other than the authors according to procedures approved by COSEPUP and the Report Review Committee.

The National Academy of Sciences (NAS) is a private, nonprofit, self-perpetuating society of distinguished scholars engaged in scientific and engineering research, dedicated to the furtherance of science and technology and to their use for the general welfare. Under the authority of the charter granted to it by Congress in 1863, the Academy has a working mandate that calls on it to advise the federal government on scientific and technical matters. Dr. Bruce M. Alberts is president of NAS.

The National Academy of Engineering (NAE) was established in 1964, under the charter of NAS, as a parallel organization of distinguished engineers. It is autonomous in its administration and in the selection of members, sharing with NAS its responsibilities for advising the federal government. The National Academy of Engineering also sponsors engineering programs aimed at meeting national needs, encourages education and research, and recognizes the superior achievements of engineers. Dr. William A. Wulf is president of NAE.

The Institute of Medicine (IOM) was established in 1970 by NAS to secure the services of eminent members of appropriate professions in the examination of policy matters pertaining to the health of the public. The Institute acts under the responsibility given to NAS in its congressional charter to be an adviser to the federal government and, on its own initiative, to identify issues of medical care, research, and education. Dr. Kenneth I. Shine is president of IOM.

The Committee on Science, Engineering, and Public Policy (COSEPUP) is a joint committee of NAS, NAE, and IOM. It includes members of the councils of all three bodies.

Financial Support: The development of this report was supported by the National Research Council.

Internet Access: This report is available on COSEPUP's World Wide Web site at http://www2.nas.edu/ cosepup.

\section{Limited copies are available from:}

Committee on Science, Engineering, and Public Policy

National Academy of Sciences

2101 Constitution Ave., NW

Washington, DC 20418

or e-mail: cosepup@nas.edu

Copyright 1998 by the National Academy of Sciences. All rights reserved. This document may be reproduced solely for educational purposes without the written permission of the National Academy of Sciences.

Printed in the United States of America 


\section{COMMITTEE ON SCIENCE, ENGINEERING, AND PUBLIC POLICY}

PHILLIP A. GRIFFITHS (Chair), Director, Institute for Advanced Study, Princeton, NJ

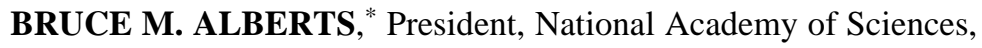
Washington, DC

WILLIAM F. BRINKMAN, Vice President, Physical Sciences Research, Lucent Technologies, Murray Hill, NJ

PETER DIAMOND, Professor of Economics, Massachusetts Institute of Technology, Cambridge, MA

GERALD P. DINNEEN, Retired Vice President, Science and Technology, Honeywell, Inc., Edina, MN

MILDRED S. DRESSELHAUS, Institute Professor of Electrical Engineering and Physics, Massachusetts Institute of Technology, Cambridge, MA

JAMES J. DUDERSTADT, President Emeritus and University Professor of Science and Engineering, Millennium Project, University of Michigan, Ann Arbor, MI

MARYE ANNE FOX, Vice President for Research, University of Texas at Austin, Austin, TX

RALPH E. GOMORY, President, Alfred P. Sloan Foundation, New York, NY

RUBY P. HEARN, Vice President, The Robert Wood Johnson Foundation, Princeton, NJ

PHILIP W. MAJERUS, Professor of Medicine, Biochemistry and Molecular Biophysics and Director, Division of Hematology-Oncology, Washington University School of Medicine, St. Louis, MO

JUNE E. OSBORN, President, Josiah Macy, Jr. Foundation, New York, NY

KENNETH I. SHINE, ${ }^{*}$ President, Institute of Medicine, Washington, DC

MORRIS TANENBAUM, Vice President, National Academy of Engineering, Short Hills, NJ

WILLIAM JULIUS WILSON, Malcolm Wiener Professor, Center for Social Policy, Harvard University, Cambridge, MA

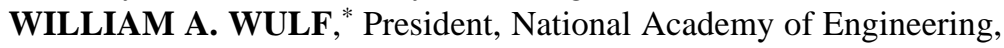
Washington, DC

MYRON F. UMAN, Interim Executive Director

DEBORAH D. STINE, Associate Director

MARION RAMSEY, Administrative Associate

\footnotetext{
*Ex officio member.
} 


\section{COSEPUP GUIDANCE GROUP}

JAMES J. DUDERSTADT (Chair), President Emeritus and University Professor of Science and Engineering, Millennium Project, University of Michigan, Ann Arbor, MI

MILDRED S. DRESSELHAUS, Institute Professor of Electrical Engineering and Physics, Massachusetts Institute of Technology, Cambridge, MA

MARYE ANNE FOX, Vice President for Research, University of Texas at Austin, Austin, TX

PHILLIP A. GRIFFITHS, Director, Institute for Advanced Study, Princeton, NJ

H. GUYFORD STEVER, Science Consultant, Gaithersburg, MD

DEBORAH D. STINE, Study Director

PATRICK P. SEVCIK, Research Associate

MICHAEL McGEARY, Consultant

NORMAN GROSSBLATT, Editor 


\section{Preface}

In 1995, a National Academy of Sciences (NAS)-National Academy of Engineering (NAE)-Institute of Medicine (IOM)-National Research Council (NRC) committee issued a report titled Allocating Federal Funds for Science and Technology.

The committee recommended development of a federal science and technology (FS\&T) budget that would reflect the real federal investment in the creation of new knowledge and technologies and exclude activities not involving the creation of new knowledge or technologies, such as the testing and evaluating of new weapons systems. An NAS panel later issued a series of reports with quantitative and qualitative assessments of the FS\&T budget.

Beginning this year, the Committee on Science, Engineering, and Public Policy (COSEPUP), a joint committee of the NAS, NAE, and IOM, will issue these annual assessments (which are available on COSEPUP's web site: http:// www2.nas.edu/cosepup). To eliminate duplicate quantitative analysis of the budget by COSEPUP, the American Association for the Advancement of Science (AAAS), in cooperation with the Academies, has now added a quantitative assessment of the FS\&T budget to its annual assessment. The results of their analysis of the FS\&T budget are presented in Appendix B and can also be seen at http://www.aaas.org.

COSEPUP is now publishing its assessment of the FS\&T budget in AAAS's annual R\&D report. The assessment is chapter 6 of AAAS's Intersociety Working Group report, AAAS Report XXIII: Research and Development FY 1999. This provides a "one-stop" assessment of the research budget and should be useful for members of Congress, the administration, federal agencies that support research, disciplinary societies, researchers, and all others involved and interested in the investment in research made by this nation. 
The committee acknowledges the invaluable information and opinions received from the participants in its planning meeting for this activity held in December 1997.

The production of the report was the result of hard work by the committee as a whole and by the extra efforts of the Guidance Group chaired by Jim Duderstadt.

The project was aided by the invaluable help of COSEPUP professional staff-Deborah D. Stine, study director, and Patrick P. Sevcik, research associate; its consultant, Michael McGeary; and editor Norman Grosblatt. A special thank you goes also to the AAAS staff of Al Teich and Kei Koizumi for their advice and analysis.

Phillip A. Griffiths, Chair

Committee on Science, Engineering, and Public Policy 


\section{Contents}

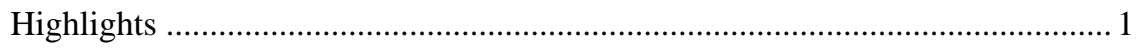

The President Proposes an Increase in the FS\&T Budget for FY 1999 .............. 2

Future Projections of the FS\&T Budget Show Funding for NIH and

NSF Increasing Dramatically above FY 1994 levels, with

the Budget for the Other Major Research Agencies Reduced ........................ 3

It is Important to Analyze the Effects of Past and Anticipated

Funding Shifts on Specific Science and Technology Fields 4

Successful Results from the Increased Funding for NIH also Depend on the Health of the Physical and Mathematical Sciences 6

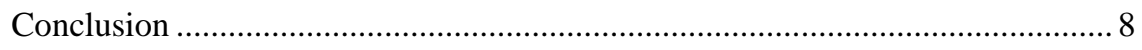

\section{ADDENDUM}

What is the Difference Between R\&D, FS\&T, and RFFA Budgets? 9

\section{APPENDIXES}

A: Data Tables

B: Figures and Tables from AAAS Report XXIII:

Research and Development FY 1999 


\section{Figures, Tables, and Boxes}

\section{FIGURES}

1: $\quad$ Trends in FS\&T, FY 1994-1999 budget authority for total FS\&T (conduct and facilities), millions of constant FY 1998 dollars, 3

2: $\quad$ FS\&T budget, by agency, FY 1994-FY 2003, 4

3: $\quad$ R\&D vs. FS\&T vs. RFFA budgets (in billions of 1999 dollars), 9

4: $\quad$ RFFA vs. FS\&T, FY 1999 (billions of dollars), 10

\section{TABLES}

1: $\quad$ Percentage Change in FS\&T Budget, FY 1994-FY 2003, 5

2: $\quad$ Real Percent Changes in Federal Obligations by Field, FY 1993-1997, 6

A-1: Trends in FS\&T, FY 1994-FY1999, Budget Authority for Total FS\&T (Conduct and Facilities), in Millions of Constant FY 1998 Dollars, 12

A-2: FS\&T Budget by Agency, FY 1994-FY 2003 (in millions of constant 1998 dollars), 12

A-3: FS\&T vs. RFFA, FY 1999 (millions of dollars), 12

\section{BOXES}

What is the FS\&T Budget?, 2

How to Get the "Best Bang" for the Federal Research Dollar, 7

Setting Goals for the Nation's Research Investment, 8 


\section{Observations on the President's Fiscal Year 1999 Federal Science and Technology Budget}

\section{HIGHLIGHTS}

In this report, the Committee on Science, Engineering, and Public Policy (COSEPUP) provides its observations on the federal science and technology (FS\&T) portion of the president's fiscal year (FY) 1999 submission. The FS\&T budget (see box) reflects the federal investment in the creation of new knowledge and technologies and excludes such activities as the testing and evaluating of new weapons systems.

Provided below are the highlights of this report

- The president's FY 1999 budget proposes an increase $^{1}$ in the FS\&T budget (a 1.3\% increase over the FY 1998 budget in constant dollars). This proposed increase would bring FS\&T to within 1.8\% of its FY 1994 level in constant dollars.

- The National Institutes of Health (NIH) and the National Science Foundation (NSF) have received increased investment since 1994. NIH's FY 1999 FS\&T budget would be $21.3 \%$ larger than its FY 1994 budget in real terms. NSF's would be $14.3 \%$ larger.

- The FS\&T budgets of other agencies that support research and graduate education and have important influences on the development of specific fields (such as physical sciences, engineering, computer science, and mathematics) have declined since FY 1994. Funding for FS\&T in these agencies as a group would be down by $11.0 \%$ from FY 1994.

- The cross-cutting initiatives in the president's budget target national goals requiring broad investment by a number of research agencies. Issues addressed in FY 1999 include climate-change technology, large-scale networking and high-end computing and computation, education, and emerging infectious diseases. Cross-cutting initiatives can be important in making the nation's federal research investment more efficient and effective.

\footnotetext{
${ }^{1}$ COSEPUP recognizes that the increases in the FS\&T budget are based on an uncertain funding source - the tobacco settlement — and that there are issues regarding the caps on discretionary spending.
} 


\section{What is the FS\&T Budget?}

In 1995, the National Academy of Sciences (NAS)-National Academy of Engineering (NAE)-Institute of Medicine (IOM)-National Research Council issued a report titled Allocating Federal Funds for Science and Technology. For the United States to maintain its leadership in science and technology, this report recommended increased coherence in federal science and technology (FS\&T) budgeting. Given the always limited budgets for research, Congress and the administration could free funds for important new opportunities by reducing support for less-important activities (see http://www2.nas.edu/cosepup).

The report recommended development of an FS\&T budget that would reflect the real federal investment in the creation of new knowledge and technologies and exclude activities not involving the creation of new knowledge or technologies, such as the testing and evaluating of new weapons systems. It would amount in FY 1999 to about $\$ 47.1$ billion, compared with the $\$ 77.7$ billion currently reported as federal research and development.

The FS\&T budget includes the funding for basic and applied research of all departments and agencies (including "6.1" and "6.2" at the Department of Defense) and all civilian development funding, but only the part of defense development at the Department of Defense (DOD) and the Department of Energy (DOE) that includes generic technology development ("6.3" at DOD and its equivalent in the DOE atomic energy defense program).

- The president proposes a Research Fund for America (RFFA) that highlights $\$ 31$ billion of the nondefense budget as a priority. As noted by Franklin Raines, director of the Office of Management and Budget (OMB), the RFFA is closely patterned on the Academies' Allocating Federal Funds report, which called for an integrated FS\&T budget. Unlike FS\&T, the RFFA does not include defense-related research.

\section{THE PRESIDENT PROPOSES AN INCREASE IN THE FS\&T BUDGET FOR FY 1999}

The president's budget for FY 1999 includes \$47.1 billion for FS\&T, an increase of $1.3 \%$ over FY 1998 in constant dollars ${ }^{2}$; this represents an increase in the nation's investment in the creation of new knowledge and technologies.

\footnotetext{
${ }^{2}$ The GDP deflator, which was about $2.2 \%$ per year in the 1994-1999 period (and is expected to continue through 2003), is used by both COSEPUP and AAAS in calculating constant-dollar figures.
} 


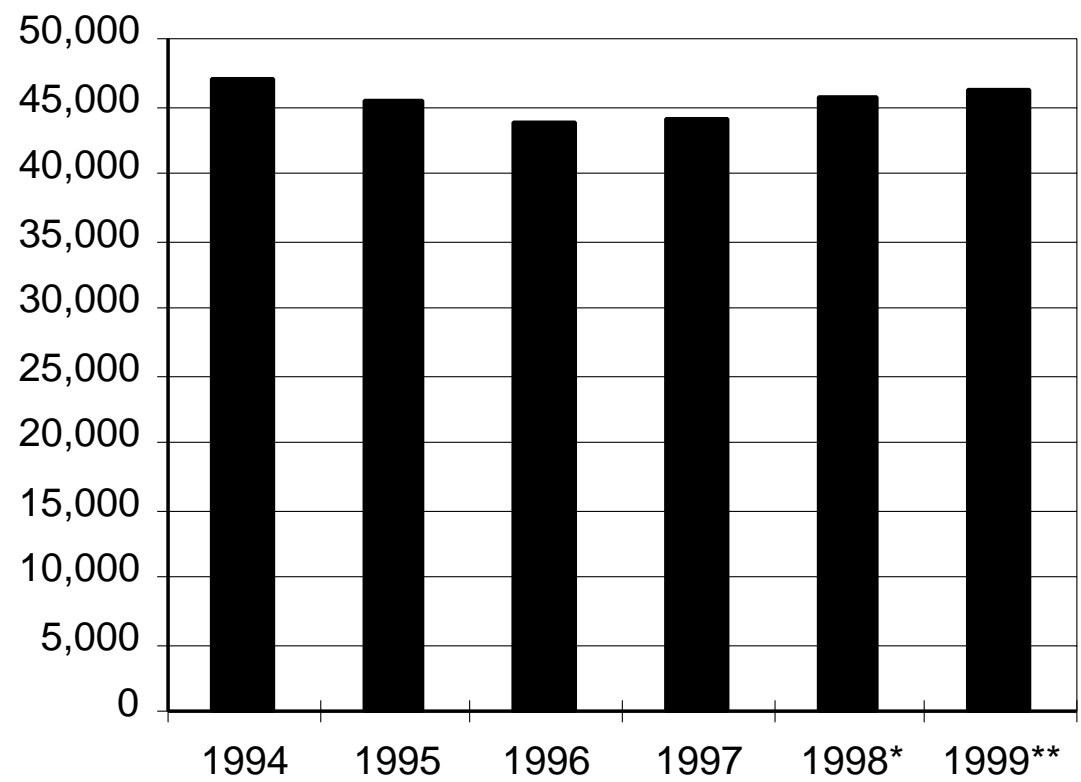

FIGURE 1 Trends in FS\&T, FY 1994-1999 budget authority for total FS\&T (conduct and facilities), millions of constant FY 1998 dollars. *Appropriated, **Requested.

The proposed increase for FY 1999 would bring FS\&T to within $1.8 \%$ of its FY 1994 level in constant dollars (see figure 1; more in-depth information is provided in table A-1). This proposal constitutes a change in administration policy from a year ago, when the president's FY 1998 submission projected flat budgets for FS\&T through FY 2002.

\section{FUTURE PROJECTIONS OF THE FS\&T BUDGET SHOW FUNDING FOR NIH AND NSF INCREASING DRAMATICALLY ABOVE FY 1994 LEVELS, WITH THE BUDGET FOR THE OTHER MAJOR RESEARCH AGENCIES REDUCED}

Figure 2 shows the current and projected change in the FS\&T funding for four key research agencies: NSF, NIH, DOE, and DOD. The percentage change for various periods is shown in table 1 (for more in-depth information, see table A-2). From the base year of FY 1994 to the projection for FY 2003, NIH funding would increase by $52 \%$ and NSF funding by $19 \%$ (in constant dollars). The FS\&T budget for the other major research agencies, however, will have declined from FY 1994; DOE funding will have decreased by $11 \%$ and DOD by $26 \%$ over this period. 


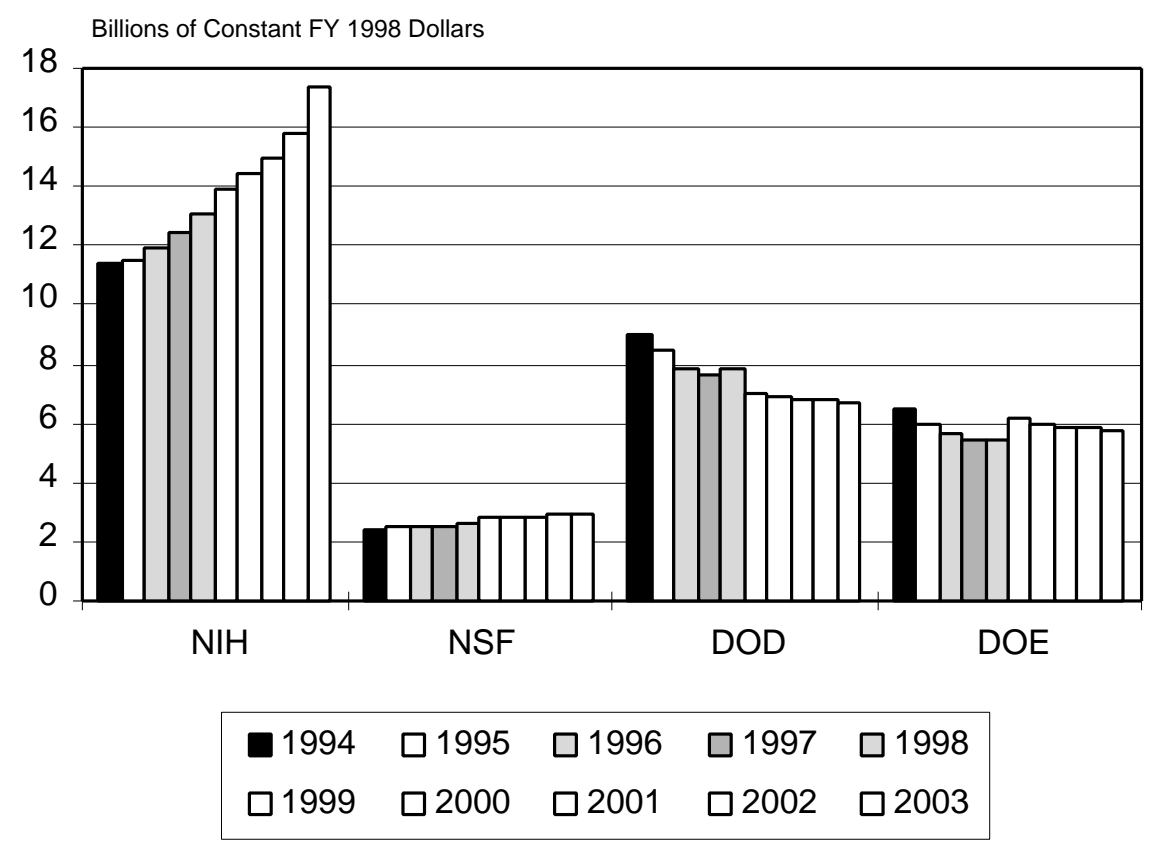

FIGURE 2 FS\&T budget, by agency, FY 1994-FY 2003. Note: Budget authority for FY 1994-1997 is actual, for 1998 estimated, for 1999 requested, and for 2000-2003 as projected by OMB. Constant dollars were calculated with the GDP deflator.

\section{IT IS IMPORTANT TO ANALYZE THE EFFECTS OF PAST AND EXPECTED FUNDING SHIFTS ON SPECIFIC SCIENCE AND TECHNOLOGY FIELDS}

NIH's FS\&T budget would be 21.3\% larger in FY 1999 (by \$2.4 billion in FY 1998 dollars) than in FY 1994 in real terms. NSF's would be 14.3\% larger (by $\$ 0.4$ billion in FY 1998 dollars). The FS\&T budget for the four other major research agencies as a group would be 11.0\% smaller in FY 1999 (by \$3.7 FY 1998 dollars) than in 1994. As shown in Appendix B, most of the mission research agencies-such as DOD, DOE, the US Department of Agriculture (USDA), and the National Aeronautics and Space Administration (NASA) — would continue to have smaller FS\&T budgets than they had in FY 1994.

How does such a shift in federal funding patterns affect specific scientific and engineering fields? The agencies with reduced FS\&T budgets are the major supporters of research and graduate education in some fields, and they provide a critical component of support for the national science and engineering enterprise. For example, agencies other than NIH and NSF provide $92 \%$ of federal funding 
TABLE 1 Percentage Changes in FS\&T Budget, FY 1994-FY 2003 (constant dollars)

\begin{tabular}{|c|c|c|c|}
\hline & FY 1998-1999 & FY 1994-1999 & FY 1994-2003 \\
\hline Agency & Change, $\%$ & Change, $\%$ & Change, $\%$ \\
\hline NIH & +6.0 & +21.3 & +51.9 \\
\hline NSF & +9.1 & +14.3 & +18.5 \\
\hline DOD & -9.7 & -22.2 & -25.7 \\
\hline DOE & +13.5 & -4.7 & -10.8 \\
\hline
\end{tabular}

of research in physics, $85 \%$ in computer science, and $90 \%$ in engineering. That research is performed by intramural federal laboratories and extramural industrial laboratories, universities and colleges, federally funded R\&D centers, and other nonprofit and government entities. For universities and colleges, agencies other than NIH and NSF support substantial percentages of the research performed in those fields: $69 \%$ in physics, $69 \%$ in computer science, and $57 \%$ in engineering. ${ }^{3}$

Table 2 provides the only recent funding data available by broad field. The data, collected by NSF, provide information on actual and estimated obligations from FY 1993 to FY 1997. Total federal spending on basic and applied research ${ }^{4}$ in constant dollars declined by 1.2\% from FY 1993 (its high point) to FY 1997 (see table 2). Although spending by NIH and NSF was up by $6.8 \%$, this increase was more than offset by reductions in the FS\&T budgets of other agencies.

The increased NSF support for academic engineering research compensated for cuts in DOD support; how this has affected the engineering fields supported primarily by DOD is worth investigating. Cuts in the other fields of concern have not necessarily been offset by proportional increases elsewhere. For example, increases in support by NIH and NSF for academic research in the environmental and social/behavioral sciences have not compensated for decreased support from the other agencies; they are down $5.1 \%$ and $7.3 \%$ respectively.

DOD, NASA, DOE, and other mission agencies provide a substantial proportion of federal funding for graduate students in the fields where they are the major federal funders- $47 \%$ in physical sciences, $58 \%$ in mathematics, $64 \%$ in computer science, and $67 \%$ in engineering. Funding changes that affect those agencies might also affect the amount of graduate-student support that is available for students in those fields. For example, the number of science and engineering graduate students for whom DOD is the primary source of funding de-

\footnotetext{
${ }^{3}$ Calculated from tables C23-C26 (all performers) and C68-C-71 (universities and colleges) in NSF, Federal Funds for Research and Development, Fiscal Years 1995, 1996, and 1997, Vol. 45, Detailed Statistical Tables. NSF 97-327. Arlington, VA: National Science Foundation, 1997.

${ }^{4}$ This part of the analysis focuses on obligations for research as opposed to R\&D, because NSF does not collect statistics on development funding by field.
} 
TABLE 2 Real Percentage Changes in Federal Obligations by Field, FY 1993-FY 1997 (constant dollars)

\begin{tabular}{|c|c|c|c|c|c|c|}
\hline \multirow[b]{3}{*}{ Field } & \multicolumn{6}{|l|}{ Change, $\%$} \\
\hline & \multicolumn{3}{|c|}{ Total Research } & \multicolumn{3}{|c|}{ Academic Research } \\
\hline & $\mathrm{NIH}+\mathrm{NSF}$ & All Others & Total & $\mathrm{NIH}+\mathrm{NSF}$ & All Others & Total \\
\hline All fields & +6.8 & -6.4 & -1.2 & +5.0 & -13.1 & -0.2 \\
\hline Life sciences & +6.4 & -2.2 & +4.0 & +2.6 & -10.8 & +1.0 \\
\hline Physical sciences & -0.7 & -11.0 & -9.6 & -4.2 & -9.5 & -7.3 \\
\hline Environmental sciences & +8.9 & +2.1 & +3.1 & +4.0 & -13.5 & -5.1 \\
\hline \multicolumn{7}{|l|}{ Mathematics and } \\
\hline Computer science & +4.1 & +17.7 & +14.8 & -3.3 & +1.8 & -0.4 \\
\hline Engineering & +62.4 & -10.0 & -5.5 & +77.3 & -15.9 & +11.0 \\
\hline Social and Behavioral & +13.1 & -5.8 & +2.4 & +3.4 & -37.5 & -7.3 \\
\hline
\end{tabular}

Note: Obligations are the amounts for grants and contracts awarded, orders placed, services received, and similar commitments during a given period, regardless of when the funds were appropriated or of whether future payments are required.

Source: Calculated from NSF 97-327 (FY 1995-FY 1997), 96-319 (total research, FY 1993-FY 1994), and NSF 96-318 (academic research, FY 1993-FY 1994).

creased from 9,315 in 1993 to 8,470 in $1996^{5}$. An in-depth study is warranted to learn the effect of the above funding changes for key science and engineering fields, including the effect on the number and quality of the graduate students in each field.

\section{SUCCESSFUL RESULTS FROM THE INCREASED FUNDING FOR NIH ALSO DEPEND ON THE HEALTH OF THE PHYSICAL AND MATHEMATICAL SCIENCES}

As indicated in the NAS Beyond Discovery series ${ }^{6}$, which uses well-known applications of science and technology to illustrate how research has led to breakthroughs that have greatly benefited society, every breakthrough stems from research conducted in many science and engineering fields. Although the expanded investment in health research focuses on $\mathrm{NIH}$, research results in other science and engineering fields are also critical for improving health. As indicated by Harold Varmus, director of $\mathrm{NIH}^{7}$ :

\footnotetext{
${ }^{5} \mathrm{NSF}$ and SRS, unpublished tables from survey of graduate students and postdoctorates in science and engineering, fall 1996.

${ }^{6}$ NAS, Beyond Discovery: The Path from Research to Human Benefit. Washington, DC: National Academy Press, http://www2.nas.edu/bsi.

${ }^{7}$ Varmus, H. "New Directions in Biology and Medicine," AAAS plenary lecture, Philadelphia, February 13, 1998.
} 


\title{
How to Get the Best "Bang" for the Federal Research Dollar
}

The highest-quality projects and people should be supported with FS\&T funds. As indicated in the Allocating Federal Funds report, the best way to ascertain that the highest-quality projects and people are supported is some form of competition involving rigorous evaluation of merit.

Competitive merit review involves use of criteria that include technical quality, the qualifications of the proposers, relevance and educational impacts of the proposed project, and other factors pertaining to research goals, such as the mission of the funding agency. Competition means that, at some level within the framework of an agency's mission, researchers who propose the best ideas are selected. In an open competition, anyone may apply and be funded, regardless of institution or geographic location. In the case of highly targeted missions, quality can also be maintained by knowledgeable program managers who use external scientific and technical advisory groups to help assess quality and to help monitor whether agency needs are being met.

Judgment in the application of merit review is warranted because it is not a perfect system. What is defined as merit and who determines merit are key ingredients.

\begin{abstract}
Most of the revolutionary changes that have occurred in biology and medicine are rooted in new methods. Those, in turn, are usually rooted in fundamental discoveries in many different fields. Some of these are so obvious that we lose sight of them-like the role of nuclear physics in producing the radioisotopes essential for most of modern medical science. Physics also supplied the ingredients fundamental to many common clinical practices- $\mathrm{X}$ rays, CAT scans, fiber optic viewing, laser surgery, ECHO cardiography and fetal sonograms. Materials science is helping with new joints, heart valves, and other tissue mimetics. Likewise, an understanding of nuclear magnetic resonance and positron emissions was required for the imaging experiments that allow us to follow the location and timing of brain activities that accompany thought, motion, sensation, speech, or drug use. Similarly, X-ray crystallography, chemistry, and computer modeling are now being used to improve the design of drugs, based on threedimensional protein structures... . These are but few of many examples of the dependence of biomedical sciences on a wide range of disciplines-physics, chemistry, engineering and many allied fields.
\end{abstract}

Some observers have suggested that in this post-Cold War era we should shift away from partitioning R\&D into civilian and noncivilian categories and instead use such categories as health versus nonhealth research. Because of the intimate synergistic relationships between the disciplines of science and the re- 


\section{Setting Goals for the Nation's Research Investment}

In its 1993 report Science, Technology and the Federal Government: National Goals for a New Era, COSEPUP proposed two primary research goals for federal funding of research: the United States should perform at least at world-class levels in all major fields of science, and the United States should seek preeminence in a select number of fields (see http:// www2.nas.edu/cosepup).

The goal that US scientists and engineers should work at the forefront of all major fields is necessary if the United States is to maintain its competitive position in the long term. We must be able to educate effectively the next generation of scientists and engineers and to assimilate and extend modern breakthroughs in different fields.

When should we single out particular fields of science for special support? Preeminence might be desired for a field that is tightly coupled to national objectives. Or a field might so powerfully affect other fields as to have a multiplicative effect on scientific advances. One field might hold overriding importance because it captures the public imagination.

Biomedical research is an example of a field in which preeminence is desired. Providing the best possible health care for our citizens and sustaining the strength of our biomedical industry are clearly national objectives.

To assess the status of various research fields, COSEPUP recommended "benchmarking" assessments by experts to determine the relative position of the United States in particular fields of science and engineering. COSEPUP has been conducting several tests of this concept. The first two, on mathematics and on materials science and engineering, have been released; a third, on immunology, will be released in the fall of 1998 (see http://www2.nas.edu/cosepup).

search activities of various federal agencies, however, such categories would obscure the interconnectedness of research and could fragment the scientific community.

\section{CONCLUSION}

In conclusion, an FS\&T analysis of the president's FY 1999 R\&D budget shows that it represents increased investment in the nation's science and engineering research compared with FY 1998.

Since FY 1994, NIH and NSF have received increased funding in real terms. This trend is projected by the administration to continue to FY 2003. The potential impact of decreased funding by DOE and DOD on support of research and 
graduate students in fields integral to national economic development needs to be examined. In addition, because NIH's efforts in health research also depend heavily on research that is supported by other agencies, the impact of funding changes needs to be examined here as well.

\section{ADDENDUM}

\section{How Do the R\&D, FS\&T, and RFFA Budgets Differ?}

As shown in figure 3, the R\&D budget is $\$ 77.7$ billion, the FS\&T budget is $\$ 47.1$ billion, and the RFFA is $\$ 31.1$ billion. What are the differences between these three budgets?

The R\&D budget incorporates all basic and applied R\&D funded by the federal government. R\&D funding normally includes personnel, program-supervision, and administrative-support costs directly associated with R\&D activities; laboratory equipment is also included. Defense R\&D includes testing, evaluation, prototype development, and other activities that precede actual production (known as RDT\&E). Funding for R\&D facilities includes construction, repair, or alteration of physical plant (reactors, wind tunnels, particle accelerators, or laboratories) used in the conduct of $R \& D$. It also includes capital (major) equipment used in the conduct of $R \& D$. Independent $R \& D$ (IR\&D) is not included. (IR\&D allows contractors to recover a portion of in-house $R \& D$ costs through overhead payments on federal procurement contracts.) More information is available in appendices $1 \& 2$.

The FS\&T budget includes the civilian and noncivilian research budget for all agencies (including 6.1 and 6.2 at DOD) and the development budget for all agencies except DOD and DOE. For the development budget of the latter two agencies, only DOD 6.3 budget categories and the equivalent activities at DOE are included in the FS\&T budget.

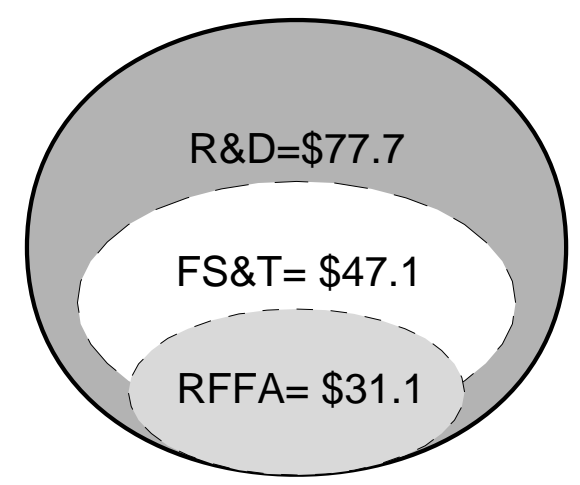

FIGURE 3 R\&D vs. FS\&T vs. RFFA budgets (in billions of dollars). 


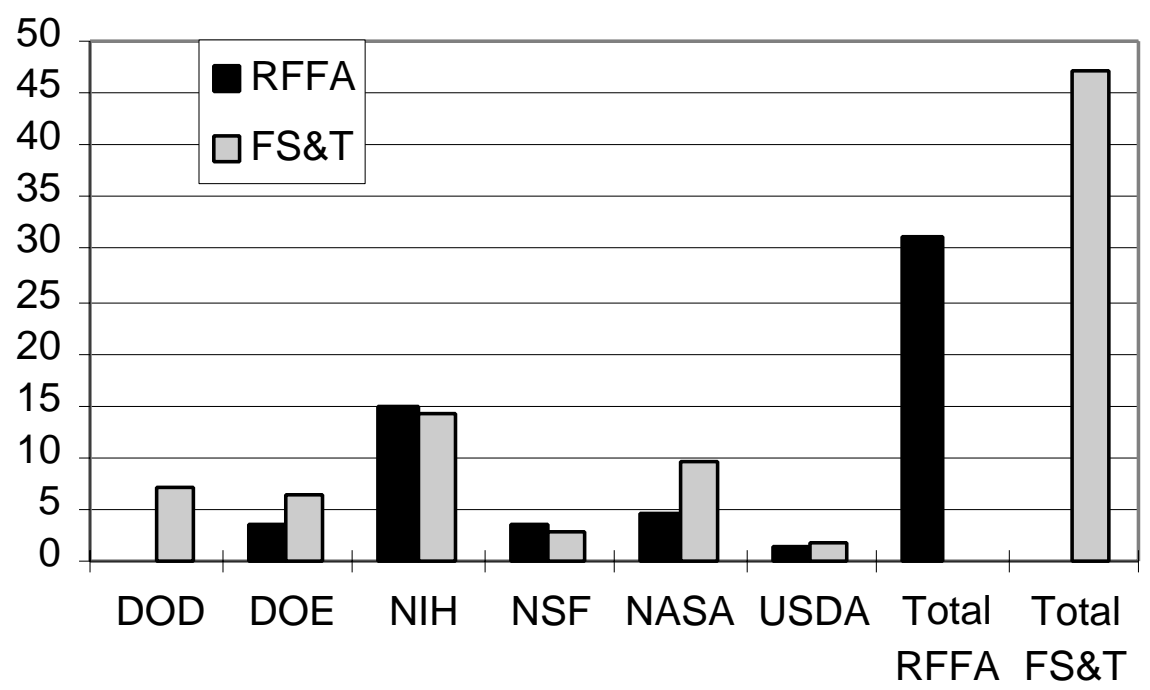

FIGURE 4 RFFA vs. FS\&T, FY 1999 (billions of dollars).

The \$31.1 billion RFFA budget emphasizes presidential priorities within the civilian portion of the R\&D budget and another $\$ 3$ billion of funds not classified as R\&D. Of the $\$ 37$ billion civilian R\&D budget, it includes $95 \%$ ( $\$ 15$ billion) of funds for basic research, 77\% (\$9 billion) for applied research, and 49\% (\$4 billion) for development. The multiyear focus of the RFFA provides long-term emphasis on these priorities. It does not include the space station at NASA.

The president's budget submission does not explicitly define the characteristics of what is in the RFFA. The RFFA does not include the FS\&T budgets of a number of small agencies that have research programs. It does include about $\$ 3$ billion in programs, primarily at NSF and NIH, that are not classified as R\&D according to OMB categories.

A comparison of the RFFA and the FS\&T budget for the six largest research agencies is shown in figure 4 (in-depth information is provided in table A-3). Although it does not include defense-related research, the RFFA is an important step toward an integrated budget like the FS\&T. 


\section{APPENDIX A


TABLE A-1 Trends in FS\&T, FY 1994-FY 1999. Budget Authority for Total FS\&T (Conduct and Facilities), in millions of constant FY 1998 dollars

\begin{tabular}{llllll}
\hline & \multicolumn{2}{l}{ Federal S\&T } & & \multicolumn{2}{l}{ Federal R\&D } \\
\cline { 2 - 3 } Fiscal Year & Current \$M & Constant \$M & & Current \$M & Constant \$M \\
\hline 1994 & 43,002 & 46,997 & & 71,074 & 77,677 \\
1995 & 42,688 & 45,485 & & 70,948 & 75,597 \\
1996 & 42,162 & 43,910 & & 71,232 & 74,185 \\
1997 & 43,340 & 44,161 & & 73,934 & 75,335 \\
1998 & 45,557 & 45,557 & & 76,038 & 76,038 \\
1999 & 47,057 & 46,134 & & 77,735 & 76,211 \\
Chg. FY 1998-FY1999 & $+3.3 \%$ & $+1.3 \%$ & & $+2.2 \%$ & $+0.2 \%$ \\
Chg. FY1994-FY1999 & $+9.4 \%$ & $-1.8 \%$ & & $+9.4 \%$ & $-1.9 \%$ \\
\hline
\end{tabular}

Sources: FS\&T numbers from Table 1; R\&D from AAAS Reports

TABLE A-2 FS\&T Budget by Agency, FY 1994-FY 2003 (in millions of constant 1998 dollars)

\begin{tabular}{|c|c|c|c|c|c|c|c|c|c|c|}
\hline & $\begin{array}{l}\text { Act'1 } \\
1994\end{array}$ & $\begin{array}{l}\text { Act'1 } \\
1995\end{array}$ & $\begin{array}{l}\text { Act'l } \\
1996\end{array}$ & $\begin{array}{l}\text { Act'l } \\
1997 \\
\end{array}$ & $\begin{array}{l}\text { Est. } \\
1998\end{array}$ & $\begin{array}{l}\text { Req. } \\
1999\end{array}$ & $\begin{array}{l}\text { Prjctd } \\
2000\end{array}$ & $\begin{array}{l}\text { Prjctd } \\
2001\end{array}$ & $\begin{array}{l}\text { Prjctd } \\
2002 \\
\end{array}$ & $\begin{array}{l}\text { Prjctd } \\
2003 \\
\end{array}$ \\
\hline NIH & 11,446 & 11,467 & 11,899 & 12,449 & 13,097 & 13,885 & 14,393 & 14,956 & 15,836 & 17,381 \\
\hline NSF & 2,451 & 2,553 & 2,490 & 2,470 & 2,568 & 2,801 & 2,829 & 2,854 & 2,878 & 2,905 \\
\hline DOD & 9,052 & 8,450 & 7,857 & 7,635 & 7,800 & 7,040 & 6,951 & 6,818 & 6,758 & 6,725 \\
\hline DOE & 6,475 & 5,942 & 5,668 & 5,472 & 5,437 & 6,170 & 5,973 & 5,913 & 5,897 & 5,778 \\
\hline
\end{tabular}

TABLE A-3 FS\&T versus RFFA, FY 1999 (millions of dollars)

\begin{tabular}{lrrr}
\hline Agency & FS\&T & RFFA* & Non-RFFA FS\&T \\
\hline Dept. of Defense & 7,181 & 0 & 7,181 \\
Dept. of Health \& Human Services & 14,888 & 14,869 & 19 \\
$\quad$ National Institutes of Health $\dagger$ & 14,163 & 14,798 & -635 \\
National Aeronautics and Space Administration & 9,504 & 4,605 & 4,899 \\
Dept. of Energy & 6,293 & 3,741 & 2,552 \\
National Science Foundation & 2,857 & 3,710 & -853 \\
United States Dept. of Agriculture & 1,549 & 1,454 & 95 \\
Dept. of Commerce & 1,083 & 858 & 225 \\
Dept. of the Interior & 629 & 807 & -178 \\
Dept. of Transportation & 775 & 0 & 775 \\
Environmental Protection Agency & 657 & 692 & -35 \\
All Others & 1,641 & 360 & $1,281 * *$ \\
TOTAL FS\&T & 47,057 & 31,096 & 15,961 \\
\hline
\end{tabular}

*Of the total, $\$ 3$ billion of the RFFA is non-R\&D/FS\&T

**RFFA includes the Dept. of Veterans Affairs, Housing and Urban Development, Dept. of Education $\dagger \mathrm{NIH}$ is under the Department of Health and Human Services

$$
-12-
$$




\section{APPENDIX B}

\section{Figures and Tables from AAAS Report XXIII: Research and Development FY 1999}




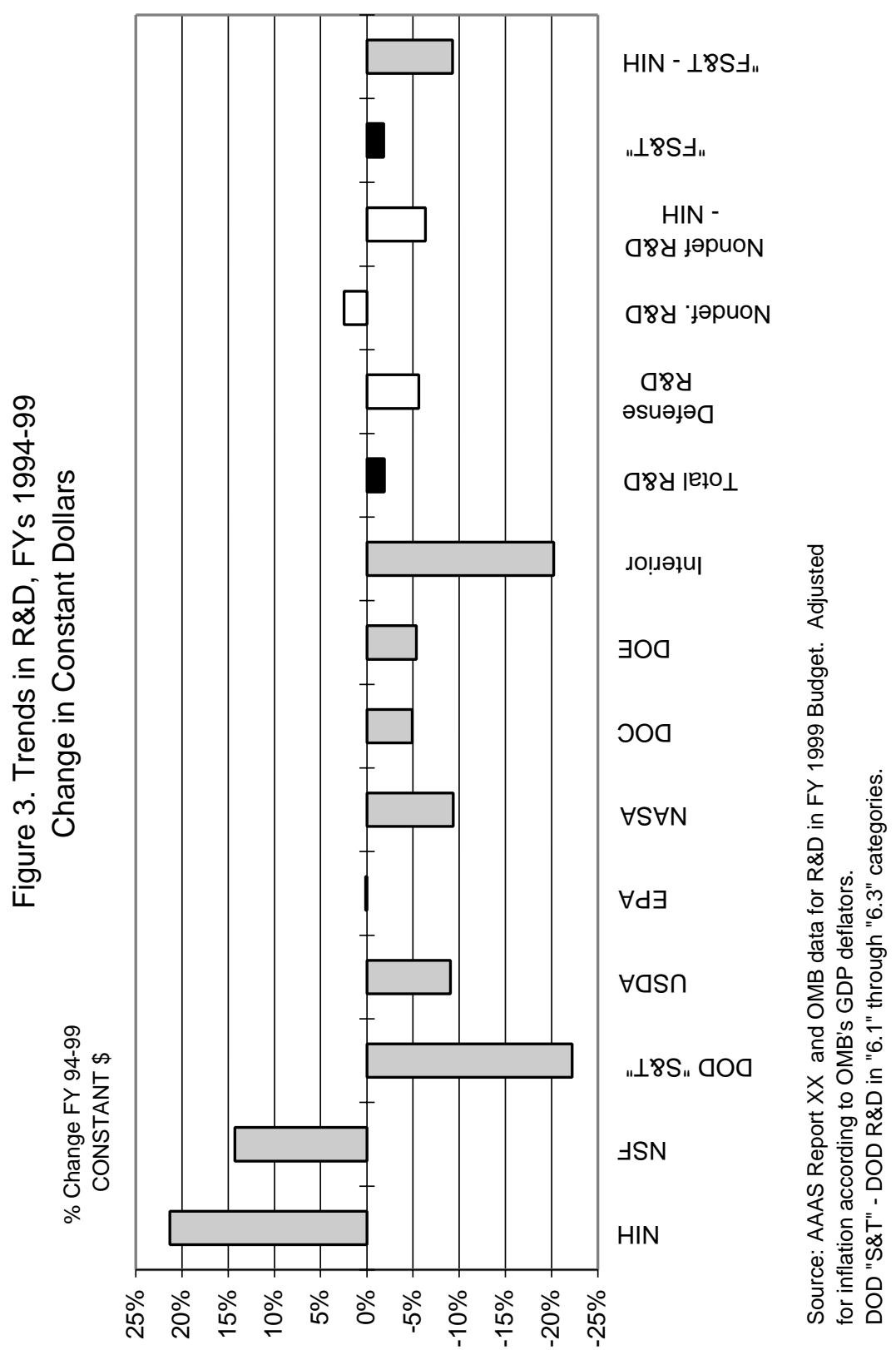


Table I-13. Trends in R\&D, FY 1994-1999

Change in Constant Dollars

\begin{tabular}{|c|c|c|c|c|c|}
\hline & \multirow{2}{*}{$\begin{array}{r}\text { FY } 1994 \\
\text { Actual } \\
\end{array}$} & \multirow{2}{*}{$\begin{array}{l}\text { FY } 1998 \\
\text { Estimate } \\
\end{array}$} & \multirow{2}{*}{$\begin{array}{r}\text { FY } 1999 \\
\text { Budget } \\
\end{array}$} & \multicolumn{2}{|c|}{$\%$ Chg. in Constant \$ } \\
\hline & & & & FY $94-98$ & FY 94-99 \\
\hline Dept. of Defense & 35,510 & 37,430 & 37,010 & $-3.6 \%$ & $-6.5 \%$ \\
\hline$D O D 6.1-6.3$ & 8,283 & 7,800 & 7,181 & $-13.8 \%$ & $-22.2 \%$ \\
\hline NASA & 9,406 & 9,816 & 9,504 & $-4.5 \%$ & $-9.4 \%$ \\
\hline Dept. of Energy & 6,771 & 6,288 & 7,142 & $-15.0 \%$ & $-5.4 \%$ \\
\hline Nat'I Institutes of Health & 10,474 & 13,097 & 14,163 & $14.4 \%$ & $21.3 \%$ \\
\hline NSF & 2,243 & 2,568 & 2,857 & $4.8 \%$ & $14.3 \%$ \\
\hline Agriculture & 1,528 & 1,553 & 1,549 & $-7.0 \%$ & $-9.1 \%$ \\
\hline Interior & 708 & 609 & 629 & $-21.3 \%$ & $-20.2 \%$ \\
\hline Transportation & 641 & 676 & 775 & $-3.5 \%$ & $8.5 \%$ \\
\hline EPA & 588 & 672 & 657 & $4.6 \%$ & $0.1 \%$ \\
\hline Commerce & 1,022 & 1,081 & 1,083 & $-3.2 \%$ & $-4.9 \%$ \\
\hline All Other & 2,185 & 2,248 & 2,365 & $-5.8 \%$ & $-2.9 \%$ \\
\hline Total R\&D & 71,074 & 76,038 & 77,735 & $-2.1 \%$ & $-1.9 \%$ \\
\hline Defense R\&D & 38,299 & 40,409 & 40,289 & $-3.5 \%$ & $-5.6 \%$ \\
\hline Nondefense R\&D & 32,775 & 35,629 & 37,446 & $-0.5 \%$ & $2.5 \%$ \\
\hline Basic Research & 13,693 & 15,710 & 16,917 & $5.0 \%$ & $10.8 \%$ \\
\hline "FS\&T" 1 & 43,002 & 45,557 & 47,057 & $-3.1 \%$ & $-1.8 \%$ \\
\hline
\end{tabular}

Source: AAAS Report XX, OMB R\&D data, and revised

agency R\&D estimates. Adjusted for inflation according to OMB's GDP deflators.

* - Includes non-NIH programs in Health and Human Services.

${ }^{1}$ An alternative measure for the federal investment in science and technology proposed by the National Academy of Sciences. This measure includes all federal R\&D except for advanced development, testing and evaluation work in DOD and DOE.

The DOD 6.1-6.3 categories represent the DOD contribution to the FS\&T budget. DOE FS\&T includes nearly all DOE R\&D; the changes to DOE FS\&T are $-16.0 \%$ (FY 94-98) and $-4.7 \%$ (FY 94-99)

Complete historical data (86-99) tables are available on the World Wide Web at: http://www.aaas.org/spp/dspp/rd/rdwwwpg.htm in the "Guide" section. 


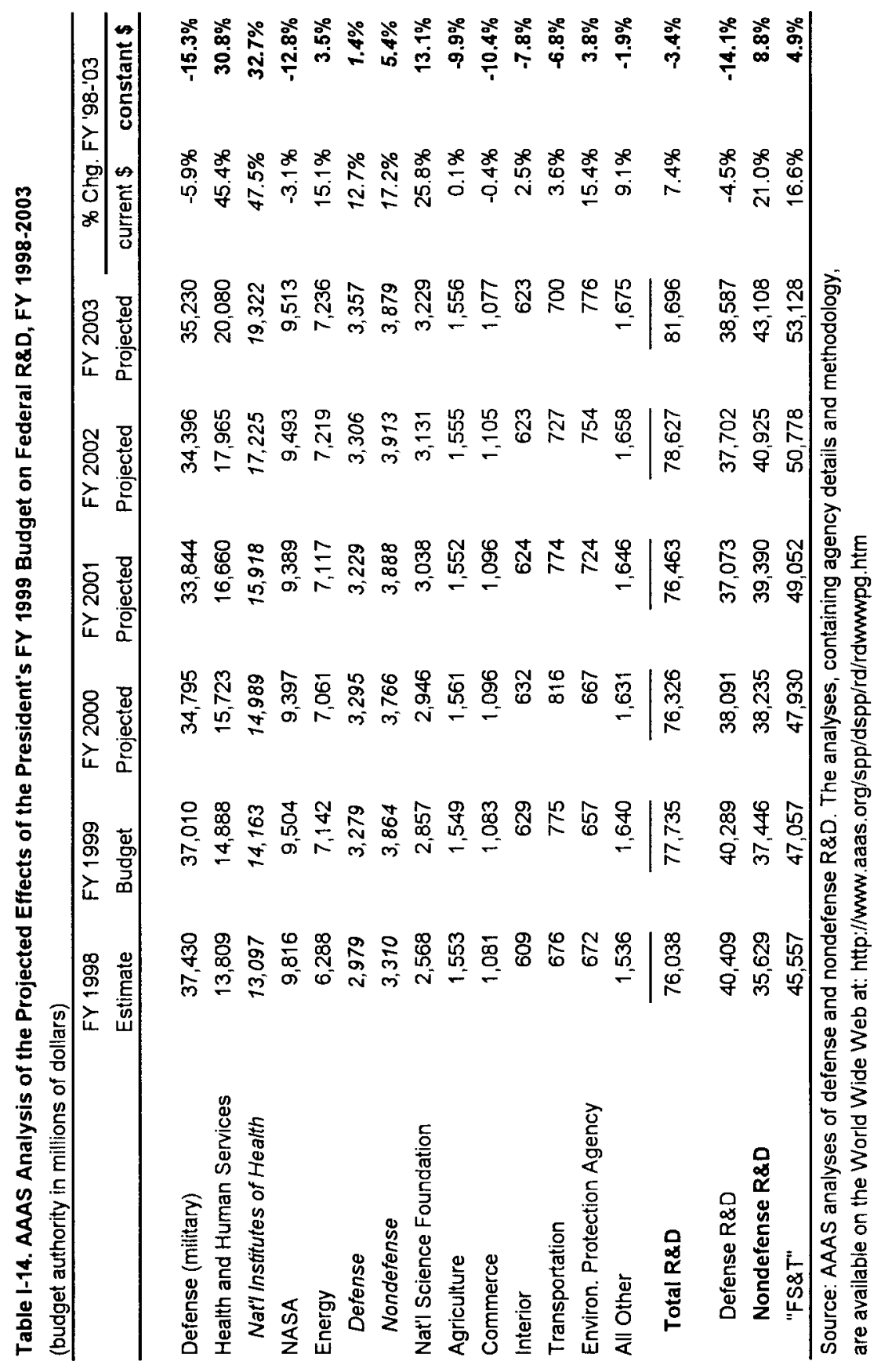


Table II-1. R\&D in the FY 1999 Budget by Agency

(budget authority in millions of dollars)

\begin{tabular}{|c|c|c|c|c|c|}
\hline & \multirow{2}{*}{$\begin{array}{c}\text { FY } 1997 \\
\text { Actual } \\
\end{array}$} & \multirow{2}{*}{$\begin{array}{l}\text { FY } 1998 \\
\text { Estimate }\end{array}$} & \multirow{2}{*}{$\begin{array}{l}\text { FY } 1999 \\
\text { Budget }\end{array}$} & \multicolumn{2}{|c|}{ Change FY 98-99 } \\
\hline & & & & Amount & Percent \\
\hline \multicolumn{6}{|c|}{ Total R\&D (Conduct and Facilities) } \\
\hline Defense (military) & 37,238 & 37,430 & 37,010 & -420 & $-1.1 \%$ \\
\hline Science \& Tech. (6.1-6.3) & 7,493 & 7,800 & 7,181 & -619 & $-7.9 \%$ \\
\hline All Other DOD R\&D & 29,745 & 29,630 & 29,829 & 199 & $0.7 \%$ \\
\hline Health and Human Services & 12,912 & 13,809 & 14,888 & 1,079 & $7.8 \%$ \\
\hline Nat'/ Institutes of Health & 12,217 & 13,097 & 14,163 & 1,066 & $8.1 \%$ \\
\hline NASA & 9,352 & 9,816 & 9,504 & -312 & $-3.2 \%$ \\
\hline Energy & 6,217 & 6,288 & 7,142 & 854 & $13.6 \%$ \\
\hline Nat'I Science Foundation & 2,424 & 2,568 & 2,857 & 290 & $11.3 \%$ \\
\hline Agriculture & 1,556 & 1,553 & 1,549 & -4 & $-0.3 \%$ \\
\hline Commerce & 964 & 1,081 & 1,083 & 2 & $0.2 \%$ \\
\hline Interior & 591 & 609 & 629 & 21 & $3.4 \%$ \\
\hline Transportation & 612 & 676 & 775 & 99 & $14.6 \%$ \\
\hline Environ. Protection Agency & 595 & 672 & 657 & -15 & $-2.3 \%$ \\
\hline Veterans Affairs & 588 & 608 & 670 & 62 & $10.2 \%$ \\
\hline Education & 185 & 209 & 265 & 56 & $26.8 \%$ \\
\hline Agency for Int'I Develop. & 169 & 150 & 154 & 4 & $2.7 \%$ \\
\hline Smithsonian & 142 & 146 & 155 & 9 & $6.2 \%$ \\
\hline Tennessee Valley Auth. & 52 & 37 & 35 & -2 & $-5.4 \%$ \\
\hline Labor & 35 & 71 & 33 & -38 & $-53.5 \%$ \\
\hline Nuclear Reg. Comm. & 62 & 61 & 53 & -8 & $-13.1 \%$ \\
\hline Corps of Engineers & 44 & 42 & 40 & -2 & $-4.8 \%$ \\
\hline Housing and Urban Dev. & 34 & 37 & 50 & 13 & $35.1 \%$ \\
\hline Justice & 48 & 65 & 60 & -5 & $-7.7 \%$ \\
\hline Social Security & 8 & 18 & 30 & 12 & $66.7 \%$ \\
\hline Postal Service & 68 & 56 & 59 & 3 & $5.4 \%$ \\
\hline Int'I Security Assist. & 21 & 21 & 21 & 0 & $0.0 \%$ \\
\hline Treasury & 13 & 13 & 13 & 0 & $0.0 \%$ \\
\hline Arms Ctrl. \& Disarm. & 1 & 1 & 1 & 0 & $0.0 \%$ \\
\hline Marine Mammal Com. & 1 & 1 & 1 & 0 & $0.0 \%$ \\
\hline Total R\&D & 73,934 & 76,038 & 77,735 & 1,697 & $2.2 \%$ \\
\hline Defense R\&D & 40,047 & 40,409 & 40,289 & -120 & $-0.3 \%$ \\
\hline Nondefense R\&D & 33,886 & 35,629 & 37,446 & 1.817 & $5.1 \%$ \\
\hline "FS\&T" 1 & 43,340 & 45,557 & 47,057 & 1,500 & $3.3 \%$ \\
\hline
\end{tabular}


Table II-1 (continued). R\&D in the FY 1999 Budget by Agency (budget authority in millions of dollars)

\begin{tabular}{|c|c|c|c|c|c|}
\hline & \multirow{2}{*}{$\begin{array}{c}\text { FY } 1997 \\
\text { Actual } \\
\end{array}$} & \multirow{2}{*}{$\begin{array}{l}\text { FY } 1998 \\
\text { Estimate }\end{array}$} & \multirow{2}{*}{$\begin{array}{l}\text { FY } 1999 \\
\text { Budget }\end{array}$} & \multicolumn{2}{|c|}{ Change FY 98-99 } \\
\hline & & & & Amount & Percent \\
\hline \multicolumn{6}{|l|}{ Conduct of R\&D } \\
\hline Defense (military) & 37,116 & 37,295 & 36,891 & -404 & $-1.1 \%$ \\
\hline Science \& Tech. (6.1-6.3) & 7,493 & 7,800 & 7,181 & -619 & $-7.9 \%$ \\
\hline All Other DOD Conduct & 29,623 & 29,495 & 29,710 & 215 & $0.7 \%$ \\
\hline Health and Human Services & 12,687 & 13,577 & 14,639 & 1,062 & $7.8 \%$ \\
\hline Nat'/ Institutes of Health & 11,994 & 12,867 & 13,915 & 1,048 & $8.1 \%$ \\
\hline NASA & 9,038 & 9,529 & 9,184 & -345 & $-3.6 \%$ \\
\hline Energy & 5,443 & 5,485 & 6,195 & 710 & $12.9 \%$ \\
\hline Nat'I Science Foundation & 2,248 & 2,357 & 2,655 & 298 & $12.6 \%$ \\
\hline Agriculture & 1,384 & 1,431 & 1,470 & 39 & $2.7 \%$ \\
\hline Commerce & 918 & 929 & 984 & 55 & $5.9 \%$ \\
\hline Interior & 582 & 601 & 622 & 21 & $3.5 \%$ \\
\hline Transportation & 591 & 656 & 757 & 101 & $15.4 \%$ \\
\hline Environ. Protection Agency & 570 & 641 & 636 & -5 & $-0.9 \%$ \\
\hline Veterans Affairs & 267 & 276 & 304 & 28 & $10.1 \%$ \\
\hline Education & 185 & 206 & 255 & 49 & $23.8 \%$ \\
\hline Agency for Int'I Develop. & 169 & 150 & 154 & 4 & $2.7 \%$ \\
\hline Smithsonian & 137 & 141 & 149 & 8 & $5.7 \%$ \\
\hline Tennessee Valley Auth. & 52 & 37 & 35 & -2 & $-5.4 \%$ \\
\hline Labor & 35 & 71 & 33 & -38 & $-53.5 \%$ \\
\hline Nuclear Reg. Comm. & 62 & 61 & 53 & -8 & $-13.1 \%$ \\
\hline Corps of Engineers & 44 & 42 & 40 & -2 & $-4.8 \%$ \\
\hline Housing and Urban Dev. & 34 & 37 & 50 & 13 & $35.1 \%$ \\
\hline Justice & 48 & 65 & 60 & -5 & $-7.7 \%$ \\
\hline Social Security & 8 & 18 & 30 & 12 & $66.7 \%$ \\
\hline Postal Service & 68 & 56 & 59 & 3 & $5.4 \%$ \\
\hline Int'l Security Assist. & 21 & 21 & 21 & 0 & $0.0 \%$ \\
\hline Treasury & 13 & 13 & 13 & 0 & $0.0 \%$ \\
\hline Arms Ctrl. \& Disarm. & 1 & 1 & 1 & 0 & $0.0 \%$ \\
\hline Marine Mammal Com. & 1 & 1 & 1 & 0 & $0.0 \%$ \\
\hline Total Conduct of R\&D & 71,723 & 73,697 & 75,290 & 1,593 & $2.2 \%$ \\
\hline Defense & 39,591 & 39,871 & 39,699 & -172 & $-0.4 \%$ \\
\hline Nondefense & 32,132 & 33,826 & 35,591 & 1,765 & $5.2 \%$ \\
\hline
\end{tabular}


Table II-1 (continued). R\&D in the FY 1999 Budget by Agency (budget authority in millions of dollars)

\begin{tabular}{|c|c|c|c|c|c|}
\hline & \multirow{2}{*}{$\begin{array}{c}\text { FY } 1997 \\
\text { Actual } \\
\end{array}$} & \multirow{2}{*}{$\begin{array}{l}\text { FY } 1998 \\
\text { Estimate }\end{array}$} & \multirow{2}{*}{$\begin{array}{l}\text { FY } 1999 \\
\text { Budget }\end{array}$} & \multicolumn{2}{|c|}{ Change FY 98-99 } \\
\hline & & & & Amount & Percent \\
\hline \multicolumn{6}{|c|}{ R\&D Facilities and Capital Equipment (no R\&D facilities for agencies not shown) } \\
\hline Defense (military) & 122 & 135 & 119 & -16 & $-11.9 \%$ \\
\hline Health and Human Services & 225 & 232 & 249 & 17 & $7.3 \%$ \\
\hline Nat'I Institutes of Health & 223 & 230 & 248 & 18 & $7.8 \%$ \\
\hline NASA & 313 & 287 & 320 & 33 & $11.4 \%$ \\
\hline Energy & 775 & 803 & 948 & 144 & $18.0 \%$ \\
\hline Nat'I Science Foundation & 177 & 211 & 202 & -8 & $-4.0 \%$ \\
\hline Agriculture & 172 & 123 & 80 & -43 & $-35.2 \%$ \\
\hline Commerce & 46 & 152 & 100 & -52 & $-34.4 \%$ \\
\hline Interior & 9 & 7 & 7 & 0 & $0.0 \%$ \\
\hline Transportation & 21 & 20 & 18 & -2 & $-10.0 \%$ \\
\hline Environ. Protection Agency & 25 & 31 & 21 & -10 & $-32.3 \%$ \\
\hline Veterans Affairs & 321 & 332 & 366 & 34 & $10.2 \%$ \\
\hline Education & 0 & 3 & 10 & 7 & $233.3 \%$ \\
\hline Smithsonian & 5 & 5 & 6 & 1 & $20.0 \%$ \\
\hline Total R\&D Facils. & 2,210 & 2,341 & 2,445 & 104 & $4.5 \%$ \\
\hline Defense & 456 & 538 & 590 & 52 & $9.7 \%$ \\
\hline Nondefense & 1,755 & 1,803 & 1,855 & 52 & $2.9 \%$ \\
\hline
\end{tabular}

Source: AAAS, based on OMB data for R\&D for FY 1999, agency budget justifications, and information from agency budget offices.

Note: The projected inflation rate between FY 1998 and FY 1999 is 2.0 percent.

${ }^{1}$ An alternative measure for the federal investment in science and technology proposed by the National Academy of Sciences. This measure includes all federal R\&D except for advanced development, testing and evaluation work in DOD and DOE. See Chapter 6 . 
Table II-2. R\&D in the Department of Defense (budget authority in millions of dollars)

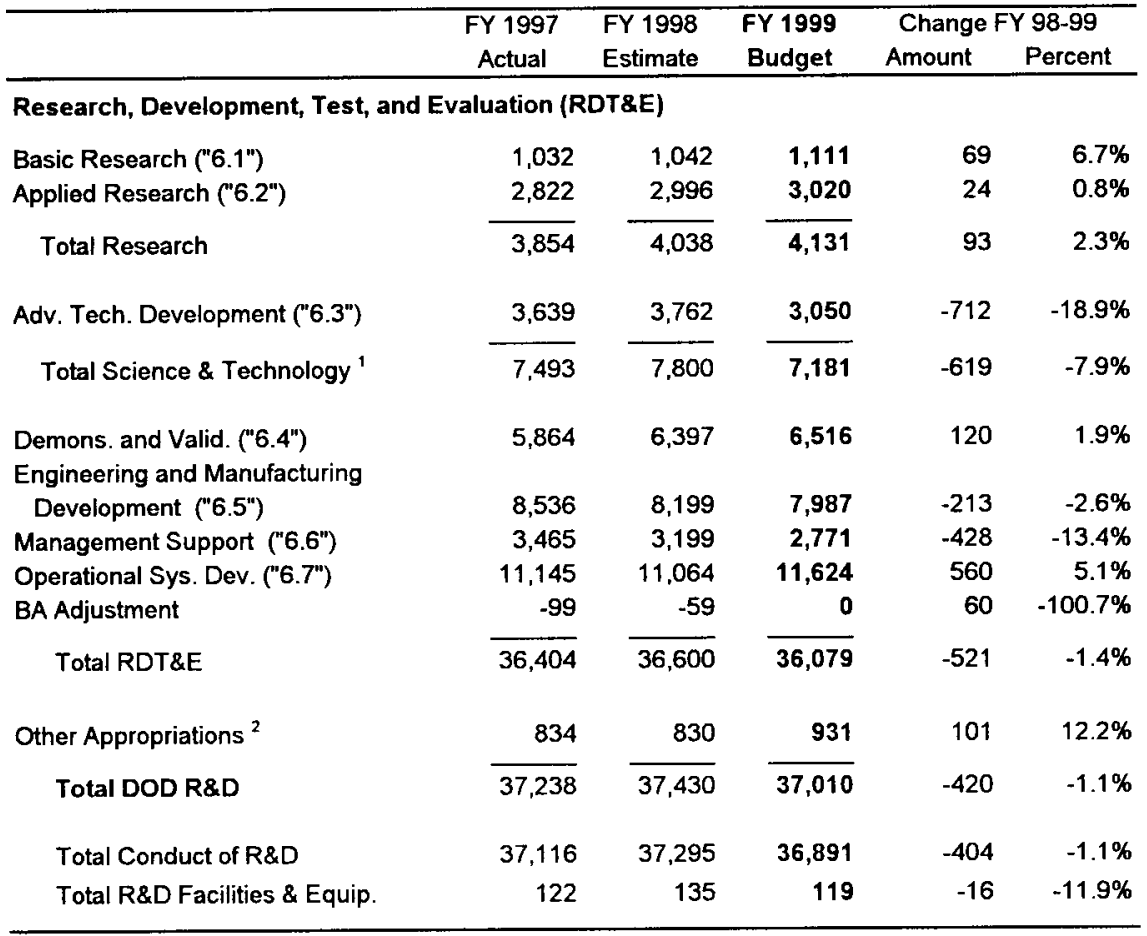

Source: OMB data for R\&D for FY 1999, Budget of the United States Government FY 1999, and DOD "RDT\&E Programs" (R-1).

1 This represents DOD's contribution to the "FS\&T" budget (see Chapter 6).

${ }^{2}$ R\&D support in military personnel, military construction, and other appropriations. Character of work ("6.x" categories) are expressed in total obligational authority (TOA).

BA Adjustment converts TOA into budget authority.

DOD Military Budget (in BILLIONS of dollars budget authority)

\begin{tabular}{lrrrrr}
\hline & FY 1997 & FY 1998 & FY 1999 & \multicolumn{2}{c}{ Change FY 98-99 } \\
& Actual & Estimate & Budget & Amount & Percent \\
\hline RDT\&E (see above) & 36.4 & 36.6 & 36.1 & -0.5 & $-1.4 \%$ \\
Military Personnel & 70.3 & 69.7 & 70.8 & 1.1 & $1.6 \%$ \\
Operations and Maintenance & 92.3 & 94.4 & 94.8 & 0.4 & $0.4 \%$ \\
Procurement & 42.9 & 44.8 & 48.7 & 3.9 & $8.7 \%$ \\
Military Construction & 5.7 & 5.1 & 4.3 & -0.8 & $-15.5 \%$ \\
Family Housing & 4.1 & 3.8 & 3.5 & -0.3 & $-8.7 \%$ \\
Revolving and Management Funds & 7.7 & 2.0 & 0.6 & -1.5 & $-71.1 \%$ \\
Allowances and Offsets & -1.5 & -1.5 & -1.5 & 0.0 & $-2.2 \%$ \\
Total DoD Budget & & & & & \\
\cline { 2 - 6 } & 258.0 & 254.9 & 257.3 & 2.4 & $0.9 \%$
\end{tabular}

DOD military budget only (excludes civilian activities of the Corps of Engineers).

$$
-20-
$$


Table II-11. R\&D in the Department of Energy (budget authority in millions of dollars)

\begin{tabular}{|c|c|c|c|c|c|}
\hline & \multirow{2}{*}{$\begin{array}{c}\text { FY } 1997 \\
\text { Actual }\end{array}$} & \multirow{2}{*}{$\begin{array}{l}\text { FY } 1998 \\
\text { Estimate }\end{array}$} & \multirow{2}{*}{$\begin{array}{c}\text { FY } 1999 \\
\text { Budget }\end{array}$} & \multicolumn{2}{|c|}{ Change FY 98-99 } \\
\hline & & & & Amount & Percent \\
\hline \multicolumn{6}{|c|}{ Summary of DOE R\&D (see notes at end of table): } \\
\hline 1. Energy Supply ${ }^{1}$ & 583.8 & 550.4 & 709.0 & 158.6 & $28.8 \%$ \\
\hline 2. Science ${ }^{1}$ & $2,220.8$ & $2,228.2$ & $2,445.2$ & 217.1 & $9.7 \%$ \\
\hline 3. Fossil Energy & 286.6 & 276.1 & 295.0 & 18.9 & $6.9 \%$ \\
\hline 4. Energy Conservation & 319.1 & 355.8 & 454.6 & 98.8 & $27.8 \%$ \\
\hline 5. Atomic Energy Defense & $2,809.2$ & $2,978.6$ & $3,278.6$ & 300.0 & $10.1 \%$ \\
\hline 6. Clean Coal Technology ${ }^{2}$ & -2.1 & -101.0 & -40.0 & -- & -- \\
\hline Total DOE R\&D & $6,217.4$ & $6,288.1$ & $7,142.4$ & 854.3 & $13.6 \%$ \\
\hline
\end{tabular}

1. Energy Supply ${ }^{\prime}$ (does not include non-R\&D components)

\begin{tabular}{|c|c|c|c|c|c|}
\hline Solar and Renewable Energy & 237.1 & 266.9 & 356.8 & 89.9 & $33.7 \%$ \\
\hline Nuclear Energy & 130.3 & 61.4 & 130.7 & 69.3 & $112.9 \%$ \\
\hline Fusion Energy Sciences & 216.4 & 222.1 & 221.5 & -0.6 & $-0.3 \%$ \\
\hline Total Energy Supply R\&D ${ }^{1}$ & 583.8 & 550.4 & 709.0 & 158.6 & $28.8 \%$ \\
\hline
\end{tabular}

2. Science ${ }^{1}$ (does not include non-R\&D components)

$\begin{array}{lrrrrr}\text { High-Energy Physics } & 657.1 & 673.0 & 686.0 & 13.1 & 1.9 \% \\ \text { Nuclear Physics } & 310.0 & 319.8 & 332.6 & 12.8 & 4.0 \% \\ \text { Basic Energy Sciences } & & & & & \\ \quad \text { Materials Sciences } & 368.5 & 391.0 & 417.2 & 26.2 & 6.7 \% \\ \text { Chemical Sciences } & 194.5 & 200.7 & 209.6 & 8.9 & 4.4 \% \\ \text { Engineering \& Geosciences } & 40.9 & 41.2 & 44.4 & 3.2 & 7.8 \% \\ \text { Energy Biosciences } & 27.3 & 27.4 & 32.5 & 5.1 & 18.5 \% \\ \text { Equipment \& Construction } & 11.5 & 7.0 & 132.4 & 125.4 & 1791.4 \% \\ \text { Adjustment } & -9.7 & -4.8 & 0.0 & 4.8 & -100.0 \% \\ \quad & 633.0 & 662.5 & 836.1 & 173.6 & 26.2 \% \\ \quad \text { Total BES } & & & & & \\ \text { Computational and Technology Research } & & & & & \\ \quad \text { Math., Info. and Compu. Sci. } & 114.8 & 127.2 & 141.3 & 14.1 & 11.1 \% \\ \text { Laboratory Technology Res. } & 23.7 & 15.8 & 16.3 & 0.5 & 3.4 \% \\ \text { Advanced Energy Projects } & 11.4 & 7.6 & 3.0 & -4.6 & -60.4 \% \\ \text { Adjustment } & -2.6 & -1.7 & 0.0 & 1.7 & -100.0 \% \\ \quad \text { Total CTR } & 147.3 & 148.9 & 160.6 & 11.8 & 7.9 \%\end{array}$


Table II-11 (continued). R\&D in the Department of Energy (budget authority in millions of dollars)

\begin{tabular}{|c|c|c|c|c|c|}
\hline & \multirow{2}{*}{$\begin{array}{c}\text { FY } 1997 \\
\text { Actual }\end{array}$} & \multirow{2}{*}{$\begin{array}{l}\text { FY } 1998 \\
\text { Estimate }\end{array}$} & \multirow{2}{*}{$\begin{array}{l}\text { FY } 1999 \\
\text { Budget } \\
\end{array}$} & \multicolumn{2}{|c|}{ Change FY 98-99 } \\
\hline & & & & Amount & Percent \\
\hline \multicolumn{6}{|c|}{ Biological and Environmental Research } \\
\hline Life Sciences & 143.5 & 165.2 & 162.0 & -3.2 & $-1.9 \%$ \\
\hline Environmental Processes & 109.1 & 108.4 & 119.2 & 10.8 & $10.0 \%$ \\
\hline Environmental Remediation & 34.9 & 66.3 & 67.4 & 1.1 & $1.7 \%$ \\
\hline Medical Apps./ Measurement & 56.6 & 66.0 & 43.9 & -22.1 & $-33.4 \%$ \\
\hline Construction & 36.1 & 0.0 & 0.0 & 0.0 & $\cdots$ \\
\hline Adjustment & -6.7 & -4.4 & 0.0 & 4.4 & $-100.0 \%$ \\
\hline Total BER & 373.5 & $\overline{401.5}$ & 392.6 & -8.9 & $-2.2 \%$ \\
\hline Energy Research Analyses & 1.5 & 1.3 & 1.0 & -0.3 & $-24.7 \%$ \\
\hline Univ. \& Science Education & 0.0 & 0.0 & 15.0 & 15.0 & -- \\
\hline Small Bus. Innov. Research & 79.2 & 0.0 & 0.0 & 0.0 & $-\cdot$ \\
\hline Multiprogram Lab Support & 19.2 & 21.2 & 21.3 & 0.1 & $0.4 \%$ \\
\hline Total Science $^{1}$ & $2,220.8$ & $2,228.2$ & $2,445.2$ & 217.1 & $9.7 \%$ \\
\hline
\end{tabular}

3. Fossil Energy R\&D (does not include non-R\&D components)

\begin{tabular}{|c|c|c|c|c|c|}
\hline Coal & 100.9 & 107.4 & 130.0 & 22.6 & $21.1 \%$ \\
\hline Petroleum & 45.2 & 48.6 & 50.2 & 1.6 & $3.3 \%$ \\
\hline Gas & 117.3 & 111.2 & 109.6 & -1.7 & $-1.5 \%$ \\
\hline Cooperative R\&D & 5.4 & 5.8 & 5.8 & 0.0 & $-0.1 \%$ \\
\hline Other R\&D programs & 7.0 & 7.5 & 7.6 & 0.1 & $1.4 \%$ \\
\hline Adjustments and deduct non-R\& & 10.8 & -4.4 & -8.2 & -3.8 & $84.7 \%$ \\
\hline Total Fossil Energy R\&D & 286.6 & 276.1 & 295.0 & 18.9 & $6.9 \%$ \\
\hline
\end{tabular}

4. Energy Conservation (does not include non-R\&D components)

\begin{tabular}{|c|c|c|c|c|c|}
\hline Building Technologies & 80.1 & 78.8 & 126.4 & 47.7 & $60.5 \%$ \\
\hline Industrial Technologies & 115.4 & 136.2 & 166.6 & 30.4 & $22.3 \%$ \\
\hline Transportation Technologies & 172.5 & 193.3 & 246.1 & 52.8 & $27.3 \%$ \\
\hline Adjustments and deduct non-R\& & -48.9 & -52.4 & -84.5 & -32.1 & $61.2 \%$ \\
\hline Total Energy Conservation & 319.1 & 355.8 & 454.6 & 98.8 & $27.8 \%$ \\
\hline
\end{tabular}

5. Atomic Energy Defense Activities (does not include non-R\&D components) Weapons Activities

Stockpile Stewardship

ASCI *

$151.6 \quad 223.5$

329.1

105.6

$47.2 \%$ 
Table II-11 (continued). R\&D in the Department of Energy (budget authority in millions of dollars)

\begin{tabular}{|c|c|c|c|c|c|}
\hline & \multirow{2}{*}{$\begin{array}{c}\text { FY } 1997 \\
\text { Actual }\end{array}$} & \multirow{2}{*}{$\begin{array}{l}\text { FY } 1998 \\
\text { Estimate }\end{array}$} & \multirow{2}{*}{$\begin{array}{c}\text { FY } 1999 \\
\text { Budget } \\
\end{array}$} & \multicolumn{2}{|c|}{ Change FY 98-99 } \\
\hline & & & & Amount & Percent \\
\hline Other Programs and Initiatives & 220.0 & 231.7 & 300.8 & 69.2 & $29.9 \%$ \\
\hline Core Res. and Adv. Tech. & 557.1 & 593.7 & 645.9 & 52.2 & $8.8 \%$ \\
\hline Testing Capab. \& Readiness & 166.0 & 180.4 & 183.9 & 3.5 & $1.9 \%$ \\
\hline Core Steward. Equip. \& Const & 129.6 & 150.6 & 161.7 & 11.1 & $7.3 \%$ \\
\hline Inertial Confinement Fusion & 234.6 & 215.7 & 213.8 & -1.9 & $-0.9 \%$ \\
\hline National Ignition Facility & 131.9 & 197.8 & 284.2 & 86.4 & $43.7 \%$ \\
\hline Tech. Partnerships and Edu. & 69.4 & 64.8 & 69.0 & 4.2 & $6.4 \%$ \\
\hline Adjustment & -3.4 & -0.5 & 0.0 & 0.5 & $-100.0 \%$ \\
\hline Total Stockpile Stewardship & $1,656.8$ & $1,857.8$ & $2,188.4$ & 330.6 & $17.8 \%$ \\
\hline Other Weapons Activities R\&D & 33.4 & 31.9 & 73.6 & 41.7 & $130.5 \%$ \\
\hline Total Weapons Activities R\& & $1,690.2$ & $1,889.7$ & $2,262.0$ & 372.3 & $19.7 \%$ \\
\hline Naval Reactors & 681.9 & 670.5 & 665.5 & -5.0 & $-0.7 \%$ \\
\hline Nonproliferation \& Verification & 211.9 & 210.0 & 210.0 & 0.0 & $0.0 \%$ \\
\hline Nuclear Safeguards \& Security & 24.0 & 23.6 & 23.6 & 0.0 & $0.0 \%$ \\
\hline Environmental Management & 197.5 & 180.3 & 113.0 & -67.3 & $-37.3 \%$ \\
\hline Intelligence & 3.7 & 4.5 & 4.5 & 0.0 & $0.0 \%$ \\
\hline Total Atomic Defense R\&D & $2,809.2$ & $2,978.6$ & $3,278.6$ & 300.0 & $10.1 \%$ \\
\hline 6. Clean Coal Technology ${ }^{2}$ & -2.1 & -101.0 & -40.0 & - & -- \\
\hline Total DOE R\&D & $6,217.4$ & $6,288.1$ & $7,142.4$ & 854.3 & $13.6 \%$ \\
\hline Conduct of R\&D & $5,442.7$ & $5,484.7$ & $6,194.8$ & 710.1 & $12.9 \%$ \\
\hline R\&D Facilities & 774.7 & 803.4 & 947.6 & 144.3 & $18.0 \%$ \\
\hline DOE "FS\&T" 3 & $5,369.5$ & $5,437.2$ & $6,293.0$ & 855.8 & $15.7 \%$ \\
\hline
\end{tabular}

Source: Agency budget justification and agency supporting documents.

* - Accelerated Strategic Computing Initiative.

1 DOE has changed its appropriation account structure. Programs in the General Science and Research account and selected programs in Energy Supply have been shifted to a new "Science" account. The table shows DOE programs under the new account structure.

${ }^{2}$ Negative because of rescissions and deferrals of previously appropriated funds.

3 DOE contribution to the "FS\&T" budget. Please see Chapter 6.

4 Includes $\$ 128$ million in FY 1999 for the National Spallation Neutron Source.

$$
-23-
$$


Table II-11. Department of Energy R\&D

Department of Energy Budget (budget authority in millions of dollars)

\begin{tabular}{|c|c|c|c|c|c|}
\hline & \multirow{2}{*}{$\begin{array}{c}\text { FY } 1997 \\
\text { Actual } \\
\end{array}$} & \multirow{2}{*}{$\begin{array}{l}\text { FY } 1998 \\
\text { Estimate }\end{array}$} & \multirow{2}{*}{$\begin{array}{l}\text { FY } 1999 \\
\text { Budget }\end{array}$} & \multicolumn{2}{|c|}{ Change FY 98-99 } \\
\hline & & & & Amount & Percent \\
\hline Weapons Activities & 3,911 & 4,147 & 4,500 & 353 & $8.5 \%$ \\
\hline Defense Environmental Restoration & 4,398 & 4,296 & 4,260 & -37 & $-0.9 \%$ \\
\hline Defense Facilities Closure Projects & 862 & 996 & 1,006 & 10 & $1.0 \%$ \\
\hline EM Privatization & 330 & 200 & 517 & 317 & $158.4 \%$ \\
\hline Nuclear Waste and Other Defense & 1,829 & 1,829 & 1,857 & 28 & $1.6 \%$ \\
\hline Total DOE Defense & 11,331 & 11,468 & 12,140 & 672 & $5.9 \%$ \\
\hline Science & 2,267 & 2,236 & 2,482 & 247 & $11.0 \%$ \\
\hline Energy Supply & 944 & 1,024 & 1,129 & 105 & $10.3 \%$ \\
\hline Fossil Energy & 359 & 362 & 383 & 21 & $5.8 \%$ \\
\hline Energy Conservation & 534 & 591 & 774 & 182 & $30.9 \%$ \\
\hline Other Energy Programs & 165 & 40 & 290 & 250 & $622.1 \%$ \\
\hline Non-defense Environmental Mngm & 572 & 494 & 462 & -32 & $-6.5 \%$ \\
\hline Power Marketing Administrations & 223 & 230 & 235 & 4 & $1.9 \%$ \\
\hline Departmental Administration \& IG & 154 & 115 & 139 & 24 & $20.7 \%$ \\
\hline Total DOE Budget & 16,547 & 16,561 & 18,035 & 1,474 & $8.9 \%$ \\
\hline
\end{tabular}

Source: Department of Energy budget justification.

DOE appropriations only (does not include offsets and mandatory).

Includes R\&D and non-R\&D components. 